\title{
REVISED Pathogenic helminths in the past: Much ado about
}

\section{nothing [version 3; peer review: 2 approved]}

\section{Christian Mulder (iD}

National Institute for Public Health and the Environment (RIVM), Bilthoven, 3721, The Netherlands

V3 First published: 08 Jun 2017, 6:852

https://doi.org/10.12688/f1000research.11752.1

Second version: 18 Jul 2017, 6:852

https://doi.org/10.12688/f1000research.11752.2

Latest published: 11 Aug 2017, 6:852

https://doi.org/10.12688/f1000research.11752.3

\section{Abstract}

Despite a long tradition on the extent to which Romanisation has improved human health, some recent studies suggest that Romanisation in general, and Roman sanitation in particular, may not have made people any healthier, given that in Roman times gastrointestinal parasites were apparently widespread, whilst in the present day such parasites rarely cause diseases. Unfortunately, this novel claim neglects the empirical evidence that worldwide infections in over 1.5 billion people are caused by ubiquitous foodborne nematodes. Therefore, many may wonder if fossil remains of soiltransmitted helminths have been reported in ancient sanitation infrastructures. Beneficial access to improved sanitation should always be prioritized, hence how can historical sanitation efforts have ever been harmful? In this short article, a strong plea for caution is given, asking for an augmented nematological record and showing that there is not any evidence against Roman sanitation, neither in the past nor in the present.

Keywords

Human diseases; Endoparasitic nematodes; Roman settlements; Fossil eggs.

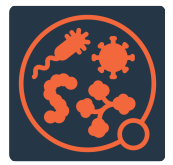

This article is included in the Pathogens

gateway.

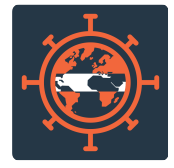

This article is included in the Neglected Tropical Diseases collection.

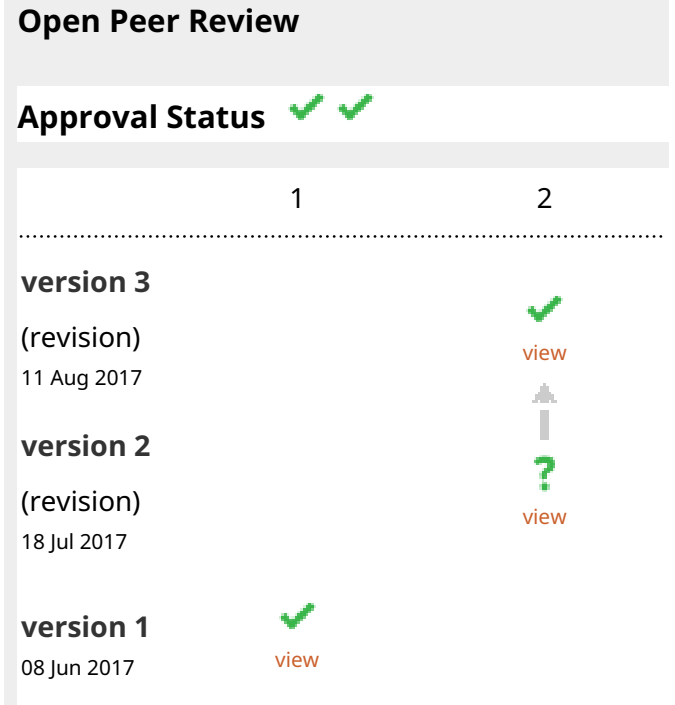

1. Karl J. Reinhard, University of Nebraska, Lincoln, USA

2. Cornelis van Tilburg, Leiden University, Leiden, The Netherlands Any reports and responses or comments on the article can be found at the end of the article. 
Corresponding author: Christian Mulder (christian.mulder@rivm.nl)

Author roles: Mulder C: Conceptualization, Writing - Original Draft Preparation, Writing - Review \& Editing

Competing interests: No competing interests were disclosed.

Grant information: The author(s) declared that no grants were involved in supporting this work.

Copyright: @ 2017 Mulder C. This is an open access article distributed under the terms of the Creative Commons Attribution License, which permits unrestricted use, distribution, and reproduction in any medium, provided the original work is properly cited.

How to cite this article: Mulder C. Pathogenic helminths in the past: Much ado about nothing [version 3; peer review: 2 approved] F1000Research 2017, 6:852 https://doi.org/10.12688/f1000research.11752.3

First published: 08 Jun 2017, 6:852 https://doi.org/10.12688/f1000research.11752.1 


\section{REVISED Amendments from Version 2}

There are apparently different views on Roman water technology, hence I improved my take-home message on public health. The suggested attempt to explain the historical occurrence of helminth eggs in urban areas by a possible increase of manure application in the countryside is challenging although out of the scope of this communication, but for those interested in that aspect I strongly recommend literature reviews like Dark \& Gent in Oxford Journal of Archaeology 20(2001):59-78 doi/10.1111/1468-0092.00123

See referee reports

In her Nature feature, Chelsea Wald ${ }^{1}$ reviewed some of the conclusions by Piers D. Mitchell ${ }^{2}$ and describes the fascinating rise of latrines in Mesopotamia, Greece and the Roman Empire. Both authors tried to point out that most of these sanitation facilities were not doing much for the residents' health, despite the idea that sophisticated plumbing systems, like those of ancient Rome, may have acted as a kind of control that could benefit even the poor. This debated interpretation was based on the fact that human hosts mainly acquire infective nematodes via the faecal-oral route through the soil, although unembryonated eggs can remain viable in the soil for 15 years. Helminth preservation seems to be the highest in moist anaerobic environments like latrines ${ }^{3}$; therefore, even
Roman latrines, with continuous flushing and related sediments (coprolites), can become valuable for the reconstruction of past gastrointestinal infections, if evaluated correctly.

As a matter of fact, water purification will always be one of the most intriguing examples of how public health and societal health are interwoven. Amazing examples come from Roman history, where water and wastewater systems rapidly became pillars for European civilisation. The large-scale introduction by Romans of fountains into or near public buildings, together with closed aqueducts, can be seen as the very first Water Safety Plan. Interestingly, archaeologists somehow seem to be ideologically motivated to conceptualize diseases and outbreaks in Roman times, despite the thin palynological record from ancient sanitation infrastructures around the Mediterranean Sea ${ }^{1,2}$ (Figure 1).

Many pathogens are reported in ancient latrines because they are intrinsically correlated to human settlements, and not to sanitation infrastructures themselves, which are supposed to reduce the risk of contact with outbreak sources. On one hand, it is true that fossil remains of roundworms, whipworms and hookworms (collectively referred to as soil-transmitted helminths) have been reported from ancient sanitation infrastructures. On the other hand, Romans were fully aware of the importance of clean water and efficient sanitation systems. Already during the short reign of

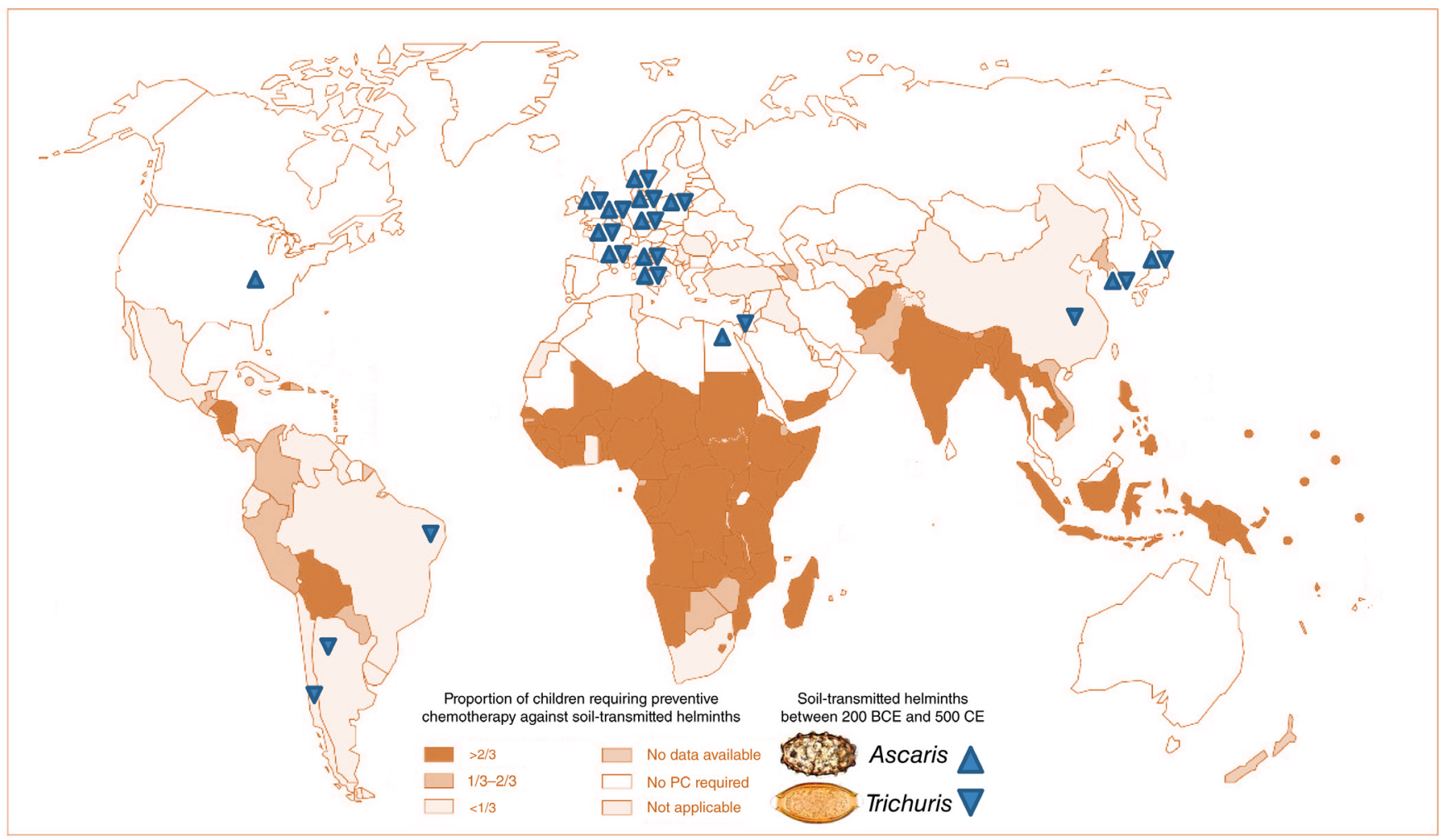

Figure 1. Multiple geographical and historical investigation bias between ancient settlements claimed to be infected in the past, and children's helminthiases in modern countries. Background map implemented with palaeoparasitological records of roundworms (Ascaris) and whipworms (Trichuris) recovered from a global selection of archaeological sites built between 200 BCE and 500 CE (Common Era) $)^{2,4-8}$. The background map has been adapted from World Health Organization, program on Control of Neglected Tropical Diseases (gamapserver. who.int/mapLibrary/Files/Maps/STH_2011_global.png). 
Nerva in Rome (96 - 98 CE), Frontinus decided that water from different sources had to be kept separate: clean water was reserved for potable use, intermediate quality water was used for recreation and only poor quality water was sent for irrigation. Thanks to sophisticated hydraulic systems for aqueducts, cisterns, pipes, therms, baths, fountains and latrines, the capital of the Roman Empire became famous as Roma regina aquarum. Due to the greatest care provided to their waters for the health and security of the capital and later of the other cities, these neglected latrines became an open archaeological window not so much on Roman sanitation, but on our civilisation as a whole. Fossilized helminth eggs in dung sediments from latrines are very peculiar tools to reconstruct migration routes, trades, animal domestication, diets, past outbreaks and even urban catastrophes ${ }^{4-6}$.

Nematodes are the most frequently occurring invertebrates. These primitive soil organisms occupy diverse trophic levels in ecological networks and can act either as antagonists for soilborne pests or be pathogens themselves. It can be dangerous to suggest that sanitation may not have made people any healthier, as humans can also get infected with soil nematodes by ingesting unclean vegetables or by contact with infected domestic animals. Along the aforementioned faecal-oral route, behavioral and allometric factors have been put forward in existing literature ${ }^{9}$, being the host-related factors linked to human size prominent. According to host-parasite regression models for mammals ${ }^{9}$ and assuming on average one adult body weight of $62.0 \mathrm{~kg}$ (corresponding to a volume of $61,400 \mathrm{cc}$ ), each infected human might contain up to 12,300 helminths.

Hence, it is not surprising to find helminths in sanitation systems of ancient settlements, especially if only the palaeoparasitological data for sites at which these pathogens were detected are gathered together. For instance, archaeological records of commonsource outbreaks can be collated to support the idea that sanitation facilities historically linked to Romanisation have widespread helminths, although these cosmopolitan endoparasites are well-known to occur during Roman times even around the Pacific Ocean, including the New World in pre-colonial times ${ }^{5,7,8,10}$ (Figure 1). Thus, we have to realize that there would be many more helminth eggs in ancient sanitation facilities if these facilities had not been there in the past. Surprisingly, archaeologists like to invert this basic framework, and suggestive interpretation may be worse than no interpretation at all.

But even if such pathogens are identified, it remains challenging either to exclude false parasitism (incidental presence in human faeces of eggs resulting from the consumption of an infected animal ${ }^{7,11}$ ) or to determine with certainty human outbreaks (helminth eggs might demonstrate their human origin by some circumstantial evidence only $y^{3,11}$ ). Allometric rules that express parasites and noninfected animals per square meter ${ }^{12}$, in tandem with the several possible contamination pathways, will always lead to diseases with a high global burden ${ }^{13}$. Moreover, a parasitic occurrence can also be related to open water contamination, for instance from livestock grazing in upland areas causing outbreaks downstreams. This has nothing to do with any sanitation structure, as these parasites are by far common and overdispersed ${ }^{14-16}$ : hot spots examples of faecal contamination, as shown by highly aggregated Ascaris or Trichuris eggs, are in fact well-known in archaeology and palaeoecology $\mathrm{y}^{11,17,18}$.

Omitting such a relevant weight of evidence in any comparison between archaeological excavations will introduce de facto a strong bias towards false-positive results into palaeoecological meta-analyses. In the future, to avoid interesting, but geographically misleading or even statistically speculative conclusions, one of the most intriguing hypotheses that will arise might be the investigation by microscopy of soils from archaeological sites associated either with one sanitation infrastructure or without that sanitation. In the case of Roman sanitation, due to the Hadrian's Wall bordering the northern part of the Roman Empire with all its social infrastructures, including latrines, England (entirely inside the Wall during Roman times) and Scotland (outside the Wall during Roman times) can together provide the perfect study area. Again, it seems necessary to emphasize that the Romans created an original system of public sanitation and water distribution on a scale not seen before simply because they linked as first individual hygiene to public health. As it is all too easy to spot patterns in randomly collected data, objective empirical evidence that correlations are real demands a well-designed survey to avoid any suspicion.

There are 2.5 billion people still living on Earth without improved sanitation facilities and an ensured availability of sanitation worldwide is one of the core United Nations targets to end poverty in 2030 (http://www.un.org/sustainabledevelopment/ sustainable-development-goals). Therefore a correct data mining of all nematological records ${ }^{19}$ combined with objective interpretation of, probably thin, circumstantial evidence will require great care, as the conclusion shall have implications on ongoing global control programs relating to helminthiases. On the other hand, as the taxonomic status of Ascaris is contentious ${ }^{20}$, palaeoecological evidence from archaeological sites in synergy with present-day molecular ecology can become an unexplored avenue to improve current control programs.

\section{Competing interests}

No competing interests were disclosed.

\section{Grant information}

The author(s) declared that no grants were involved in supporting this work. 
1. Wald C: The secret history of ancient toilets. Nature. 2016; 533(7604): 456-458. PubMed Abstract | Publisher Full Text

2. Mitchell PD: Human parasites in the Roman World: health consequences of conquering an empire. Parasitology. 2017; 144(1): 48-58.

PubMed Abstract | Publisher Full Text

3. Moore PD: Life seen from a medieval latrine. Nature. 1981; 294: 614 Publisher Full Text

4. Araújo A, Reinhard KJ, Ferreira LF, et al:: Parasites as probes for prehistoric human migrations? Trends Parasitol. 2008; 24(3): 112-115.

PubMed Abstract | Publisher Full Text

5. Reinhard KJ: Archaeoparasitology in North America. Am J Phys Anthropol. 1990; 82(2): 145-163.

PubMed Abstract | Publisher Full Text

6. Reinhard KJ, Confalonieri UE, Herrmann B, et al.: Recovery of parasite remains from coprolites and latrines: Aspects of paleoparasitological technique. Homo. 1986; 37(4): 217-239.

Reference Source

7. Gonçalves ML, Araújo A, Ferreira LF: Human intestinal parasites in the past: new findings and a review. Mem Inst Oswaldo Cruz. 2003; 98(Suppl 1): 103-118. PubMed Abstract | Publisher Full Text

8. Leles D, Reinhard K, Fugassa MH, et al:: A parasitological paradox: Why is ascarid infection so rare in the prehistoric Americas? J Archaeol Sci. 2010; 37(7): 1510-1520.

Publisher Full Text

9. George-Nascimento M, Munoz G, Marquet PA, et al:: Testing the energetic equivalence rule with helminth endoparasites of vertebrates. Ecol Lett. 2004 7(7): 527-531.

Publisher Full Text

10. Mejia R, Vicuña Y, Broncano N, et al:: A novel, multi-parallel, real-time polymerase chain reaction approach for eight gastrointestinal parasites provides improved diagnostic capabilities to resource-limited at-risk populations. Am J Trop Med Hyg. 2013; 88(6): 1041-1047.

PubMed Abstract | Publisher Full Text | Free Full Text
11. Brinkkemper $\mathrm{O}$, van Haaster $\mathrm{H}$ : Eggs of intestinal parasites whipworm (Trichuris) and mawworm (Ascaris): Non-pollen palynomorphs in archaeological samples. Rev Palaeobot Palynol. 2012; 186: 16-21. Publisher Full Text

12. Hechinger RF: Parasites help find universal ecological rules. Proc Natl Acad Sci U S A. 2015; 112(6): 1656-1657.

PubMed Abstract | Publisher Full Text | Free Full Text

13. Bethony J, Brooker S, Albonico M, et al:: Soil-transmitted helminth infections: ascariasis, trichuriasis, and hookworm. Lancet. 2006; 367(9521): 1521-1532. PubMed Abstract | Publisher Full Text

14. Reinhard K: Reestablishing rigor in archaeological parasitology. Int $J$ Paleopathol. 2017(Early View).

Publisher Full Text

15. Morand S, Krasnov B: Why apply ecological laws to epidemiology? Trends Parasitol. 2008; 24(7): 304-309. PubMed Abstract | Publisher Full Tex

16. Lester RJ, McVinish R: Does moving up a food chain increase aggregation in parasites? J R Soc Interface. 2016; 13(118): pii: 20160102. PubMed Abstract | Publisher Full Text | Free Full Text

17. Fisher $\mathrm{CL}$, Reinhard K, Kirk M, et al.: Privies and parasites: The archaeology of health conditions in Albany, New York. Hist Archaeol. 2007; 41(4): 172-197. Publisher Full Text

18. Trigg HB, Jacobucci SA, Mrozowski SA, et al:: Archaeological parasites as indicators of environmental change in urbanizing landscapes: Implications for health and social status. Am Antiq. 2017; 1-19. Publisher Full Text

19. Dallas T: helminthR: an R interface to the London Natural History Museum's Host-Parasite Database. Ecography. 2016; 39(4): 391-393. Publisher Full Text

20. Søe MJ, Kapel CM, Nejsum P: Ascaris from Humans and Pigs Appear to Be Reproductively Isolated Species. PLoS Negl Trop Dis. 2016; 10(9): e0004855.

PubMed Abstract | Publisher Full Text | Free Full Text 


\section{Open Peer Review}

\section{Current Peer Review Status:}

\section{Version 3}

Reviewer Report 22 August 2017

https://doi.org/10.5256/f1000research.13422.r24946

(C) 2017 van Tilburg C. This is an open access peer review report distributed under the terms of the Creative Commons Attribution License, which permits unrestricted use, distribution, and reproduction in any medium, provided the original work is properly cited.

\section{Cornelis van Tilburg}

Centre for the Arts in Society, Leiden University, Leiden, The Netherlands

After his revisions, I agree with the revised article of Christian Mulder.

Competing Interests: No competing interests were disclosed.

I confirm that I have read this submission and believe that I have an appropriate level of expertise to confirm that it is of an acceptable scientific standard.

\section{Version 2}

Reviewer Report 08 August 2017

\section{https://doi.org/10.5256/f1000research.13196.r24554}

(C) 2017 van Tilburg C. This is an open access peer review report distributed under the terms of the Creative Commons Attribution License, which permits unrestricted use, distribution, and reproduction in any medium, provided the original work is properly cited.

\section{Cornelis van Tilburg}

Centre for the Arts in Society, Leiden University, Leiden, The Netherlands

In Mulder's article "Pathogenic helminths in the past: Much ado about nothing", Chelsea Wald and Piers D. Mitchell state that sanitation did not improve people's health significantly, despite its sophisticated technique. In coprolites and remains of toilets throughout the Roman Empire the presence of helminth's eggs of Ascaris and Trichuris was widespread, testifying to the unhealthiness of the environment. 
Mulder states that helminths arrive in the faeces deposit (dung heap or sewer system) through the oral-faecal route; people are infected by eating infected food and drinking infected water, so that there is no immediate connection between sanitation and 'eating' helminth's eggs. Mitchell correctly observes that a concentration of faeces is a breeding-place for parasites and eggs. Faeces was used as a fertilizer in the countryside, so that helminth's eggs were spread.

Comparing ancient sanitation with modern sanitation is not without risk. Mulder's statement 'The large-scale introduction by Romans of fountains into or near public buildings, together with closed aqueducts, can be seen as the very first Water Safety Plan' (second paragraph, 'As a matter ... Sea') is disputable. The aqueducts were closed, indeed, but this construction served to prevent pollution (e.g. by pieces of wood) or even poisoning ${ }^{1}$. Moreover, ancient 'safe water' differs from modern 'safe water'2. Nowadays, 'safe water' is water without pollution of by parasites, chemicals, etc. In Antiquity, 'safe water' was clear, without smell or taste, like rain and spring water. On the other hand, the aim of the authorities was the same: to improve health and sanitation as much as possible by supplying 'safe water', but the awareness of the Romans was restricted. If necessary, surface water was filtered ${ }^{3}$, but they were unable to remove invisible but noxious elements like helminths' eggs.

In the third paragraph ('Many pathogens ... catastrophs') Mulder refers to a tripartite division of waters ('Already... irrigation'), which would be mentioned by Frontinus. I am not aware of any mention of a tripartite division of good, intermediate and bad water in Frontinus; a reference would be welcome. In ch. 11 of De aquis, Frontinus describes how the Aqua Alsietina, supplying water of less quality, was constructed for the Naumachia, a pond for reenacting sea-battles; this aqueduct was not connected with the other aqueducts, being situated on the right bank of the Tiber river. This water was not used, in the first instance, for consumption; surplus of the Naumachia was used for the irrigation of private gardens ${ }^{4}$. In the chapters 88-93, Frontinus criticizes the indiscriminate use of water from aqueducts for any purpose (for instance, the use of clear drinking water for fulleries), and pleads for separating all aqueducts; some aqueducts (like Marcia) containing excellent water have to supply drinking water, other ones (like Anio Vetus) for other purposes ${ }^{5}$.

A small correction in this paragraph: for 'terms' read 'thermae' - which, however, is already covered by 'baths'. I advise to delete this word.

Conclusion: Mulder discusses the influence of sanitation on hygiene and health in Antiquity. He disagrees with Mitchell, who states that the improvement of sanitation did not improve human health very much. Bodily hygiene increased by the use of bathhouses, but the number of helminths did not diminish due to the growing use of faeces as fertilizer. Mulder rightly argues that one should not too readily conclude that the development of sanitation did not contribute to the health of the population significantly; more research comparing areas both within and outside the Roman Empire is certainly required. Please add references of Frontinus.

\section{References}

1. van Tilburg C: Streets and Streams: Health conditions and city planning. Leiden: Primavera Pers. 2015. 100 fn. 59

2. van Tilburg C: Greek and Roman Ideas about Healthy Drinking-water in Theory and Practice. Ë̈ Journal. 2013; 5: 1-30

3. van Tilburg C: Streets and Streams: Health conditions and city planning. Leiden: Primavera Pers. 
2015. 101

4. Frontino SJ: Frontinus, the stratagems and the aqueducts of Rome, translation of C.E. Bennett. The Loeb classical library. 1925. 353

5. Frontino SJ: Frontinus, the stratagems and the aqueducts of Rome, translation of C.E. Bennett. The Loeb classical library. 1925. 421

Is the topic of the opinion article discussed accurately in the context of the current literature?

Yes

Are all factual statements correct and adequately supported by citations? Partly

Are arguments sufficiently supported by evidence from the published literature? Partly

Are the conclusions drawn balanced and justified on the basis of the presented arguments? Partly

Competing Interests: No competing interests were disclosed.

Reviewer Expertise: Traffic and medicine in the Graeco-Roman Antiquity

I confirm that I have read this submission and believe that I have an appropriate level of expertise to confirm that it is of an acceptable scientific standard, however I have significant reservations, as outlined above.

Author Response 08 Aug 2017

Christian Mulder, National Institute for Public Health and the Environment (RIVM), Bilthoven, The Netherlands

I am grateful for the comments by van Tilburg, with whom I agree that present-day microbiological criteria are inapplicable to ancient sanitation systems. However, it seems to me also relevant to state that by changing the (Hellenistic) cisterns - open streaming water cyclus into a distribution system based on streaming and flushing in pipes, the Romans provided globally the very first improvement in human health and public sanitation. Even Plinius [as mentioned by van Tilburg (2013) in the Eä Journal] reported that cistern water had to be regarded as unhealthy, clarifying the relevance of streaming waters. On the other hand, there was surely a huge difference in the water quality across the Roman Empire, with some severe historical cases of poisoning and heavy metal pollution around the borders. But the few citations by van Tilburg are neither examples of human contamination by intestinal parasites nor examples of incorrect water distribution [please read a.o. P. Pace (1983) Gli Acquedotti di Roma, pp. 330, and Rodgers' English translation of Frontinus' De Aquaeductu Urbis Romae, Liber Alter]. As a matter of fact, there has not been during the past a significant growing use of human faeces as fertilizer, but simply an increase of manure application as shown in hundreds of palynological records by the kind of coprophilous dung 
fungi recorded across Europe and in some sites of Africa. Hence, also the suggested growing use of manure did not occur in urban ecosystems (and van Tilburg correctly wrote "Faeces was used as a fertilizer in the countryside"), although in some countries this unfortunate coexistence of cattle, dogs and people remains an everyday reality. In any case, access to piped water is considered central for a prevention of soil-transmitted nematodes. This reinforces my plea for a better comparison of areas within and outside the Roman Empire and I am very happy to see that also van Tilburg sees it as required. Such pathogens are in fact known from proto- and prehistoric Europe in the Neolithic and during the La Tène culture, and after the decline of the Roman Empire in the post-medieval period as well. Hence, the mechanistic factor beyond the occurrence of helminth eggs is not the Roman water infrastructure (as suggested by archaeologists like P.D. Mitchell), but something else that has still to be discovered (Scarce vegetation cover? Poor-quality housing? Domestic behavior?). Summarizing, these pathogenic nematodes have been widely reported in archaeobotanical and palynological literature because they are intrinsically correlated to human settlements, and not to sanitation infrastructures which only reduce the risk to get in contact with such outbreak sources.

Competing Interests: No competing interests were disclosed.

Version 1

Reviewer Report 17 July 2017

https://doi.org/10.5256/f1000research.12694.r23627

(C) 2017 Reinhard K. This is an open access peer review report distributed under the terms of the Creative Commons Attribution License, which permits unrestricted use, distribution, and reproduction in any medium, provided the original work is properly cited.

\section{Karl J. Reinhard}

School of Natural Resources, University of Nebraska, Lincoln, NE, USA

Christian Mulder's "Pathogenic helminths in the past: Much ado about nothing" reveals some basic problems with the research presented by Piers Mitchell in "Human parasites in the Roman World: health consequences of conquering an empire. Parasitology". The critique recognizes that the conclusions of the study are overblown and points to errors in methods and theory. I read Mitchell's work and concur with Mulder. Mitchell does not approach the problem from the perspective of the science of archaeology nor the science of parasitology. Mulder suggests that Mitchell did not control for false parasitism through spread of eggs through the environment. In the science of archaeology, as applied to parasitology, concentrations of parasite eggs per $\mathrm{ml}$ or gr are calculated by researchers. These calculations document the distribution of eggs through strata within pits and across ancient village landscapes. This leads to statistical identification of transmission points. When these archaeological egg accumulations are verified as fecal deposits via ancillary pollen and seed analysis, then fecal contamination "hot spots" are defined. Dating of 
these points can lead to very solid information about emergence and control of geohelminths. This has been demonstrated archaeologically by the references of Fisher and Trigg's work below. Secondly, the geohelminth life cycle of ascarids seems to be misunderstood by Mitchell who asserted that people could have been infected in Roman baths.

I have a paper that has just been published addressing rigor in archaeological parasitology. This highlights the sort of issues such as false parasitism noted by Mulder.

I believe that Mulder is spot on with regard to Mitchell's assertion. I strongly recommend this work for indexing and I would hope that Mulder includes references to the work by Fisher's team and Trigg's team. The work by Trigg is in press and can be obtained via Heather Trigg or Steve Mrozowski.

Useful References:

Fisher et al. (2007) ${ }^{1}$

Trigg et al. $(2017)^{2}$

Reinhard (2017) ${ }^{3}$

\section{References}

1. Fisher CL, Reinhard K, Kirk M, DiVirgilo J: Privies and Parasites: The Archaeology of Health Conditions in Albany, New York. Historical Archaeology. 2007. 172-197

2. Trigg HB, Jacobucci SA, Mrozowski SA, Steinberg JM: Archaeological Parasites as Indictors of Environmental Change in Urbanizing Landscapes: Implications for Health and Social Status. American Antiquity. 2017. 1-19

3. Reinhard K: Reestablishing rigor in archaeological parasitology. International Journal of Paleopathology. 2017. Publisher Full Text

Is the topic of the opinion article discussed accurately in the context of the current literature?

Yes

Are all factual statements correct and adequately supported by citations? Partly

Are arguments sufficiently supported by evidence from the published literature? Yes

Are the conclusions drawn balanced and justified on the basis of the presented arguments? Yes

Competing Interests: No competing interests were disclosed.

Reviewer Expertise: Archaeoparasitology, palynology, paleoparasitology, paleonutrition, archaeobotany, palynology 
I confirm that I have read this submission and believe that I have an appropriate level of expertise to confirm that it is of an acceptable scientific standard.

The benefits of publishing with F1000Research:

- Your article is published within days, with no editorial bias

- You can publish traditional articles, null/negative results, case reports, data notes and more

- The peer review process is transparent and collaborative

- Your article is indexed in PubMed after passing peer review

- Dedicated customer support at every stage

For pre-submission enquiries, contact research@f1000.com 